\title{
Effect of Alternative Furrow Irrigation and Potassium Fertilization on Sugarcane Yield \\ Gameh, M.A. ${ }^{1}$; E.M. Ahmed ${ }^{1}$; M.R. Dardiry ${ }^{2}$ and M.A.H. Gebreel ${ }^{3}$ \\ ${ }^{1}$ Soil Sci. Dept., Fac. Agric., Assiut Univ., Assuit, Egypt. \\ ${ }^{2}$ Water Requirements \& field irrigation Dept. Res. Inst., Agric. Res. Center, Egypt. ${ }^{3}$ Soil Sci. Dept., Fac. Agric., Al-Azhar Univ., Assuit, Egypt.
}

\section{Abstract:}

A field experiment was conducted at the Experimental Farm, El-Mattana, Agriculture Research Station, Luxor, Egypt during spring season of 2013 to determine the effects of water stress on sugarcane yield and its quality as well as its response to potassium application. The experiment was laid out in split-split plots design with three replicates. The main plots were used to express irrigation regimes $(0.8,1$ and 1.2 of the cumulative pan evaporation, CPE). The split units were assigned for irrigation manners (all furrows and alternative furrows). Sub split plots were occupied by $\mathrm{K}$ levels $\left(25,50\right.$ and $75 \mathrm{Kg} \mathrm{K}_{2} \mathrm{O} /$ fed). All the experimental treatments were randomly distributed on the respective plots.

The actual evapotranspiration $\left(\mathrm{ET}_{\mathrm{a}}\right)$ values under alternative furrow irrigation treatments $\left(5215 \mathrm{~m}^{3}\right)$ were less than that under all irrigated furrow treatments $\left(5764 \mathrm{~m}^{3}\right)$ regardless to the effect of irrigation regime or potassium fertilization. The amounts of applied water were $3592.50,4979.39$ and $8134.33 \mathrm{~m}^{3} /$ fed for irrigation regime (CPE) of $0.8,1$ and 1.2, respectively. Irrigation efficiency (IE) was decreased as the percentage of soil moisture depletion increased (at 0.8 CPE). Normal irrigation with $1.2 \mathrm{CPE}$ at $75 \mathrm{Kg} \mathrm{K}_{2} \mathrm{O}$ / fed achieved the highest value of IE $(86.16 \%)$ while the lowest value $(57.52 \%)$ was recorded at normal irrigation with $0.8 \mathrm{CPE}$ and $50 \mathrm{Kg} \mathrm{K}_{2} \mathrm{O} /$ fed. The best treatment was alternative irrigated furrow at $1 \mathrm{CPE}$ when fertilized by $75 \mathrm{Kg} \mathrm{K}_{2} \mathrm{O}$ / fed since it realized the highest CWUE $\left(8.86 \mathrm{Kg}\right.$ cane $/ \mathrm{m}^{3}$ and $1.1 \mathrm{Kg}$ sugar $/ \mathrm{m}^{3}$ ). Cane yield as well as juice purity and sugar concentration declined, resulting in decreased sugar yield as irrigation intervals was increased. Also, cane yield and its quality was increased by increasing potassium fertilization level.

KeyWords: Actual evapotranspiration, Irrigation regime, Potassium fertilization, Sugarcane yield

Received on: $16 / 3 / 2015$

Accepted for publication on: 25/3/2015

Referees: Prof. Hasanein G. Hasanein Prof. Kamal K. Attia 


\section{Introduction:}

In many parts of the world, crop production is often constrained by water limitations during the growth season. The distribution and amount of irrigation water with soil characteristics and evaporation demand determine the pattern of water availability for plants over time and the ensuring crop biomass and economic yield. The great challenge of the agricultural sector is to produce more food from less water by increasing crop water productivity. To optimize crop yields in an irrigated environment, irrigation should be timed in a way that non-productive soil evaporation and drainage losses are minimized. Water deficits should coincide with the least sensitive growth stages of the crop. A full understanding of the trade-offs between yield and water savings when irrigation is withheld early in the season would aid in the design of optimal management strategies (Qureshi et al., 2002 and Sander and Bastianssen, 2004).

Water use for agriculture crops is important for adequate water management in arid and semi-arid areas when irrigation is necessary and water is limited and expensive Egypt is forced to implement serious efforts towards the equilibrium between its limited water supply and demand.

Sugarcane is a biomassproducing crop that requires substantial input of both water and nitrogen to achieve maximum yields. Sugarcane is an important industrial and cash crop which has a great economic value, especially in Egypt. Besides sugar production, sugarcane produces numerous valuable byproducts like, alcohol used by pharmaceutical in- dustry, ethanol used as a fuel, bagasse used for paper and chip board manufacturing and press mud used as a rich source of organic matter and nutrients for crop production (Lingle et al., 2000).

Wiedenfeld (2004) revealed that growth and yields of sugarcane responded primarily to the total amount of water applied. Azevedo et al. (2006) found that increases in sugarcane yield are directly and linearly correlated with increases in the consumption of water. Yield under water-limited conditions are generally associated with reduced water use efficiency (WUE). Conversely, the application of a high irrigation water volume does not necessarily result in high yield. Singels (2007) revealed that under irrigated conditions, finetuning of water management could possibly lead to higher sucrose yields, while economizing water. Singh et al. (2007) stated that water use by the ratoon crop was higher with increasing soil moisture regimes. WUE decreased with increase in irrigation water applied. At regions with water scarcity, water saving irrigation like alternate furrow irrigation is used for different crops. In furrow irrigation water infiltration in the soil surface layer occurs in horizontal and vertical directions (2-dimensional) and infiltration water front from the two adjacent furrows overlap in horizontal direction. Combined use of alternate furrow irrigation and reduced applied water is considered as water saving or partial root-zone irrigation that enhanced the water productivity (Sepaskhah and Hosseini, 2008). Therefore, the irrigation method in practice is very important in irrigation 
management to reduce water losses without yield loss. Partial root drying irrigation by alternate furrow irrigation and drip irrigation is an appropriate procedure for management of deficit irrigation. In these irrigations, deep percolation and surface evaporation are reduced and less water is used (Ahmadi et al., 2010).

Soils of Egypt are not being replenished by potassium fertilizer. This primarily has been due to misunderstanding that these alluvial soils are rich in $\mathrm{K}$ and need no extraneous application of $\mathrm{K}$ fertilizer. If total soil $\mathrm{K}$ content is adequate, the release rate in most cases has not been enough to meet crop requirements. In present, intensive and high yield oriented agriculture, there is negative $\mathrm{K}$ balance and consequently, the soils are mined of the essential nutrient. The response to $\mathrm{K}$ application is related to site and crop specific and, in many cases, to economic as well.

Potassium is an important nutrient in sugarcane development and acts as an enzyme activator in the plant metabolism such as in photosynthesis, protein synthesis and translocation of sucrose from leaves to the stalk storage tissues. Since $\mathrm{K}$ is very relevant in sugarcane growth, development, yield and quality, knowledge of the potassium distribution is of great importance for many research areas (Nilberto et al. 2013; UNSCEAR, 2000; Cesnik \& Miocque, 2004; Bierman \& Rosen, 2005; Ashley et al., 2006 and Silveira et al., 2009). Velasco et al. (2012) found that the values of potassium concentration in sugarcane leaves and stems are virtually the same, with minor fluctuations during the entire growth period. This fact is an indication that the potassium transport mechanism in each part of the plant during its growth depends on the type of plant studied. Medina et al. (2013) found that a higher concentration of potassium at the beginning of plant development and over time, there is an oscillatory behavior in this concentration in each part of the plant, reaching a lower concentration in the adult plant.

This study was conducted to determine the effects of water stress on sugarcane yield and its quality as well as its response to potassium application.

\section{Materials and Methods:}

Field experiment was carried out during spring season of 2013 at the Experimental Farm of El-Mattana Agriculture Research Station, Luxor, Egypt which lies at latitude $25^{\circ} 41^{-}$ $0^{=} \mathrm{N}$ and longitude $32^{\circ} 39^{-} 0^{=} \mathrm{E}$, the altitude of the area is $82 \mathrm{~m}$ representing semi-arid climate with hot summers and fairly cool winters. The meteorological data of El-Mattana weather station during the growth season are presented in table (1). The relevant chemical and physical properties of the investigated soil according to Page et al. (1982) and Klut (1986) are shown in Table (2 a \&b). The conducted experiment aimed at studying the effects of different irrigation regimes on water consumptive use and water use efficiency (WUS) of sugarcane crop as well as sugarcane response to potassium application. 
Table (1): Average meteorological data of a decade (2004-2013) of Aswan (the nearest to El-Mattana agrometeological station).

\begin{tabular}{|c|c|c|c|c|c|c|c|c|}
\hline Months & $\begin{array}{l}\text { Min. } \\
\text { Temp. } \\
\left({ }^{\circ} \mathrm{c}\right)\end{array}$ & $\begin{array}{c}\text { Max. } \\
\text { Temp. } \\
\left({ }^{0} \mathrm{c}\right)\end{array}$ & $\begin{array}{c}\text { AV. } \\
\text { Temp. }\end{array}$ & $\begin{array}{l}\text { Rel } \\
\text { hum } \\
(\%)\end{array}$ & $\begin{array}{l}\text { Wind } \\
\text { speed } \\
(\mathrm{m} / \mathrm{sec})\end{array}$ & $\begin{array}{c}\text { Solar } \\
\text { radiation } \\
\left(\mathbf{M j} / \mathbf{m}^{2} . d\right)\end{array}$ & $\begin{array}{c}\text { E pan } \\
(\mathrm{mm} / \mathrm{day})\end{array}$ & $\begin{array}{c}\text { ETo } \\
\text { (mm/day) }\end{array}$ \\
\hline Apr & 16.3 & 30.4 & 23.6 & 14.1 & 3.8 & 23.3 & 4.0 & 5.7 \\
\hline May & 21.7 & 31.2 & 29.9 & 14.1 & 4.1 & 28.0 & 4.5 & 7.2 \\
\hline Jun & 24.3 & 40.5 & 32.3 & 14.3 & 4.3 & 29.3 & 4.9 & 7.5 \\
\hline July & 25.1 & 40.4 & 32.7 & 16.2 & 4.1 & 29.4 & 5.2 & 7.4 \\
\hline Aug & 25.4 & 40.4 & 32.7 & 17.2 & 4.2 & 26.2 & 5.8 & 7.0 \\
\hline Sept & 23.3 & 38.4 & 30.4 & 20.1 & 4.2 & 24.7 & 5.2 & 6.3 \\
\hline Oct & 20.5 & 35.10 & 27.2 & 22.9 & 3.7 & 20.3 & 3.8 & 5.1 \\
\hline Nov & 14.7 & 28.2 & 20.8 & 30.9 & 3.5 & 17.3 & 2.1 & 3.7 \\
\hline Dec & 10.1 & 23.4 & 16.0 & 34.9 & 3.6 & 15.3 & 1.5 & 3.0 \\
\hline Jan & 8.3 & 20.5 & 13.7 & 30.2 & 3.12 & 14.2 & 1.9 & 2.9 \\
\hline Feb & 9.8 & 24.4 & 16.6 & 25.4 & 3.9 & 19.2 & 1.8 & 3.9 \\
\hline Mar & 13.0 & 29.2 & 20.7 & 19.4 & 4.2 & 23.6 & 2.0 & 5.0 \\
\hline
\end{tabular}

Table (2a): Some physical properties of the investigated soil

\begin{tabular}{|c|c|c|c|c|c|c|c|}
\hline \multirow{2}{*}{$\begin{array}{l}\text { Soil depth } \\
\text { (cm) }\end{array}$} & \multicolumn{3}{|c|}{ Particle size distribution (\%) } & \multirow{2}{*}{$\begin{array}{c}\text { Texture } \\
\text { grade }\end{array}$} & \multirow{2}{*}{$\begin{array}{c}\text { Field } \\
\text { capacity } \\
(\%)\end{array}$} & \multirow{2}{*}{$\begin{array}{c}\text { Wilting } \\
\text { point } \\
(\%) \\
\end{array}$} & \multirow{2}{*}{$\begin{array}{r}\text { Bulk } \\
\text { density } \\
\left(\mathrm{g} / \mathrm{cm}^{3}\right) \\
\end{array}$} \\
\hline & Sand & Silt & Clay & & & & \\
\hline 0-15 & 33.90 & 28.52 & 37.58 & Clay loam & 47.22 & 18.96 & 1.15 \\
\hline 15-30 & 34.15 & 27.44 & 38.41 & Clay loam & 40.91 & 17.16 & 1.25 \\
\hline $30-45$ & 32.66 & 28.82 & 38.52 & Clay loam & 42.94 & 16.22 & 1.28 \\
\hline $45-60$ & 34.43 & 29.12 & 36.45 & Clay loam & 43.46 & 15.20 & 1.34 \\
\hline
\end{tabular}


Table (2b): Some chemical properties of the investigated soil

\begin{tabular}{|c|c|c|c|c|c|c|c|c|c|c|c|c|}
\hline \multirow{2}{*}{$\begin{array}{c}\text { Soil } \\
\text { depth } \\
(\mathrm{cm})\end{array}$} & \multirow[b]{2}{*}{$\begin{array}{c}\mathrm{CaCO}_{3} \\
\%\end{array}$} & \multirow[b]{2}{*}{$\begin{array}{c}\text { O.M. } \\
(\%)\end{array}$} & \multirow[b]{2}{*}{$\underset{(1: 2.5)}{\text { pH }}$} & \multirow{2}{*}{$\begin{array}{c}\text { EC } \\
(1: 1) \\
d S \backslash m\end{array}$} & \multicolumn{8}{|c|}{ Water soluble Ions ( meq/L) (1:1) } \\
\hline & & & & & $\mathrm{CO}_{3}$ & $\mathrm{HCO}_{3}$ & Cl & $\mathrm{SO}_{4}$ & Ca & Mg & $\mathbf{N a}$ & $\mathbf{K}$ \\
\hline $0-15$ & 3.50 & 1.78 & 7.82 & 0.33 & - & 1.2 & 1.7 & 0.6 & 1.2 & 0.9 & 1.1 & 0.3 \\
\hline 15-30 & 4.10 & 1.48 & 7.87 & 0.43 & - & 1.5 & 2.3 & 0.9 & 1.7 & 1.1 & 1.5 & 0.4 \\
\hline $30-45$ & 4.50 & 1.08 & 7.95 & 0.45 & - & 1.4 & 2.5 & 0.9 & 1.7 & 1.2 & 1.5 & 0.4 \\
\hline $45-60$ & 4.60 & 0.96 & 8.01 & 0.47 & - & 1.4 & 2.7 & 0.9 & 1.8 & 1.3 & 1.6 & 0.3 \\
\hline
\end{tabular}

The experiment was laid out in split-split plots design with three replicates (Fig.1). The main plots were devoted to irrigation manners (all furrows and alternative furrows) that bounded with buffer zone $(5 \mathrm{~m}$ width) to avoid the horizontal seepage. The split units were assigned for irrigation regimes $(0.8,1$ and $1.2 \mathrm{cu}-$ mulative pan evaporation) that bounded with buffer zone $(3 \mathrm{~m}$ width) to avoid the horizontal seepage. Sub split plots were occupied by $\mathrm{K}$ levels $\left(25,50\right.$ and $75 \mathrm{Kg} \mathrm{K}_{2} \mathrm{O} /$ fed). All the experimental treatments were randomly distributed on the respective plots. The plot was $7 \mathrm{~m}$ in length and $6 \mathrm{~m}$ in width with an area of 42 $\mathrm{m}^{2}(1 / 100 \mathrm{fed})$.

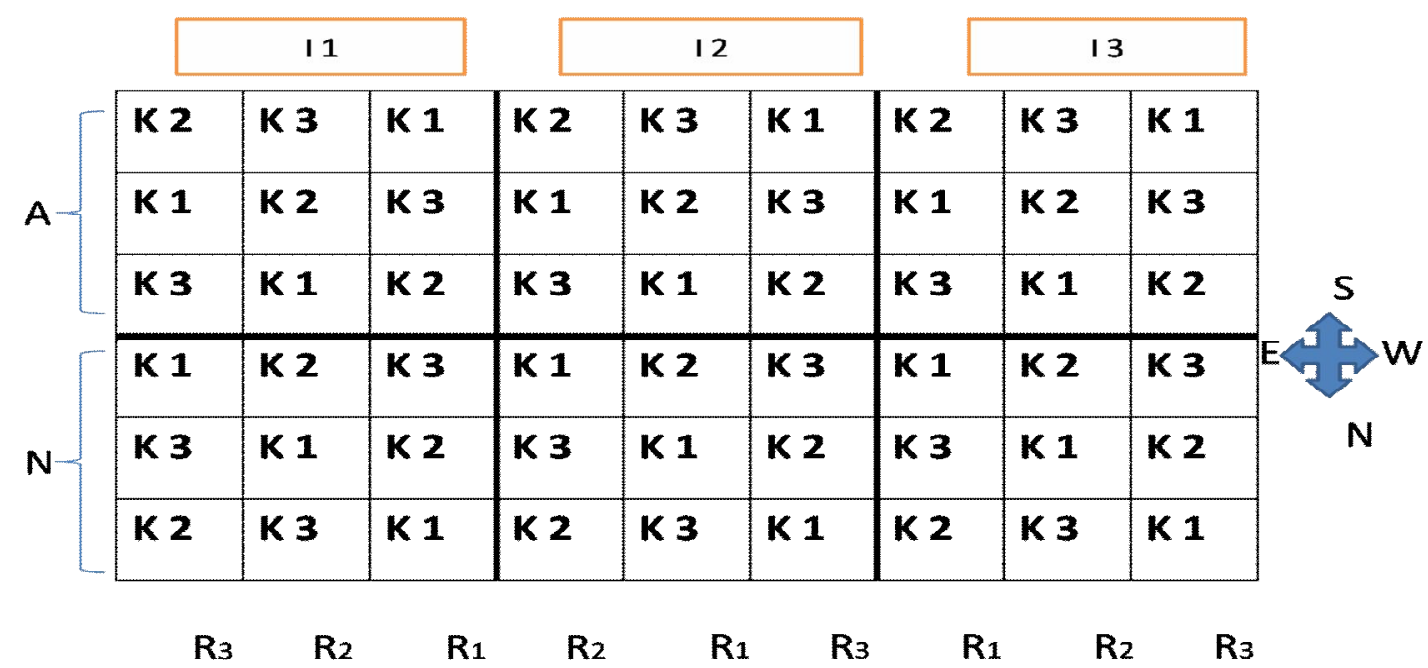

Fig. (1): Layout of the field experiment

Sugarcane cultivar G-T.54/9 was planted on April 3 ${ }^{\text {rd }}, 2013$ by placing overlapping stalk pieces in furrows spaced $1.5 \mathrm{~m}$ apart and cov- ering with approximately $10-15 \mathrm{~cm}$ of soil and it was harvested on March $15^{\text {th }}, 2014$. The study area received a flood irrigation following planting to 
establish a stand. All the agronomic practices were applied as commonly used for growing sugarcane and carried out according to the recommendation of the Ministry of Agriculture. Phosphorus fertilizer in the form of calcium super phosphate $(15.5 \%$ $\mathrm{P}_{2} \mathrm{O}_{5}$ ) was added at the rate of 350 $\mathrm{Kg} /$ fed. during soil preparation. Nitrogen fertilizer was applied in the form of urea $(46 \% \mathrm{~N})$ at the rate of $450 \mathrm{Kg} / \mathrm{fed}$. in four equal doses. The first dose was added one month after planting then the rest doses were added subsequently at one month interval. Potassium fertilizer treatments $\left(25,50\right.$ and $\left.75 \mathrm{Kg} \mathrm{K}_{2} \mathrm{O} / \mathrm{fed}\right)$ in the form of potassium sulphate $(48 \%$ $\mathrm{K}_{2} \mathrm{O}$ ) was added after three and half months from planting.

Evaporation data were obtained from a standard Class-A pan located adjacent to the experimental field and the reading was collected on a daily basis. Irrigation treatments were initiated after planting irrigation as follows:

Irrigation using 1.2 pan evaporation coefficient

Irrigation using 1.0 pan evaporation coefficient

Irrigation using 0.8 pan evaporation coefficient

Irrigation time was estimated by setting the cumulative pan evaporation to be equal to the allowable available soil moisture depletion (50\%). Reference evapotranspiration (ETo) was determined using mean monthly meteorological data according to FAO (2012). To obtain the water consumptive use, the soil moisture percentage was determined gravimetrically on dry basis just before and 24 hours after each irrigation, as well as harvesting time. At each sampling date, samples were taken from layers each of $15.0 \mathrm{~cm}$ depth from soil surface down to $60.0 \mathrm{~cm}$. The amount of water consumed from the root zone between two successive irrigations as a water depth in $\mathrm{cm}$, was calculated from the following equation: (Israelsen and Hansen, 1962).

C.U. $=\mathrm{D} \times \mathrm{B}_{\mathrm{d}} \times\left(\mathrm{Q}_{2}-\mathrm{Q}_{1}\right) / 100$

Where: C.U. $=$ actual evapotranspiration.

$\mathrm{D}=$ the irrigation soil depth (cm).

$\mathrm{B}_{\mathrm{d}}=$ bulk density of soil $\left(\mathrm{gm} / \mathrm{cm}^{3}\right)$.

$\mathrm{Q}_{2}=$ the percentage of soil moisture two days after irrigation.

$\mathrm{Q}_{1}=$ the percentage of soil moisture before next irrigation.

Field capacity (FC) and permanent wilting point (PWP) were determined using the pressure cooker and pressure membrane apparatus. A saturated undisturbed and disturbed soil sample $\mathrm{s}$ was equilibrated at suction pressures of 0.33 and 15 bar, respectively, according to Shawky (1967). The available water capacity (AWC) of a soil is the amount of water retained in the soil reservoir that can be removed by plants. This was calculated by the differences in water content at field capacity and permanent wilting point as follows: $\mathrm{AWC}=$ FC - PWP

Irrigation efficiency in this experiment was calculated using the formula of James (1988) as follows:

$$
\begin{aligned}
& \mathrm{E}_{\mathrm{a}}=\left(\mathrm{R}_{\mathrm{z}} / \mathrm{D}_{\mathrm{w}}\right) * 100 \\
& \mathrm{R}_{\mathrm{z}}=\mathrm{D}\left(\theta_{\mathrm{fc}}-\theta_{\mathrm{i}}\right) / 100
\end{aligned}
$$

Where: $\quad E a=$ efficiency of application \%

$\mathrm{Rz}=$ amount of water stored in the root zone $(\mathrm{mm})$ 
(mm)

$\mathrm{Dw}=$ depth of applied water

$\mathrm{D}=$ root zone depth $(\mathrm{mm})$

$\theta_{\text {fc }} \& \theta_{\mathrm{i}}=$ water content (V \%) at field capacity and prior to irrigation, respectively.

Water use efficiency (WUE) was calculated according to Vites (1965) using the following equation:

WUE = cane or sugar $(\mathrm{kg} / \mathrm{fed}) /$ water consumptive use ( $\mathrm{m} 3 / \mathrm{fed})$

Fresh weight cane yields were determined by harvesting and weighting all cane from the middle two rows of each plot. A random 15 stalk sample was taken from each treatment to determine stalk diameter and length from soil surface till dew-lap then crushed using a hydraulic roller mill. Juice was analyzed for total dissolved solids using a refractometer and sucrose concentration using a saccharimeter. Cane sucrose content was calculated using the Winter-Carp formula (Chen and Chou, 1993). Purity percentage was calculated according to Singh and Singh (1998) using the following formula:

Purity percentage $=($ sucrose $\%$ / brix \%) * 100

Data obtained were statistically analyzed as outlined by (Gomez and Gomez, 1984).Using means of "MSTAT-C" computer software program package according to (Freed et al., 1989).

\section{Results and Discussions:}

Irrigation water is one of the most important inputs in crop production. The arid region suffers from water shortage due to its scarcity and irregular distribution. The management of water resources in arid regions required good knowledge and great skills especially in the case of limited water supply. Adding too much or too little water may cause a serious damage for crops; therefore water requirement must be carefully determined.

\section{1- Sugarcane water relations}

Total actual evapotranspiration $\left(\mathrm{ET}_{\mathrm{a}}\right)$ as affected by irrigation regime and manner of sugarcane crop at different levels of potassium application is presented in Table (3). In general data revealed that the $\mathrm{ET}_{\mathrm{a}}$ values under alternative furrow irrigation treatments $\left(5215 \mathrm{~m}^{3}\right)$ were less than that under all irrigated furrow treatments $\left(5764 \mathrm{~m}^{3}\right)$ regardless the effect of irrigation regime or potassium fertilization. Also, there is a positive relation between the $\mathrm{ET}_{\mathrm{a}}$ values and irrigation regime or potassium fertilization. The $\mathrm{ET}_{\mathrm{a}}$ values were 3952.50, 4979.39 and $7895.66 \mathrm{~m}^{3} /$ fed for irrigation regime of $0.8,1.0$ and $1.2 \mathrm{cu}-$ mulative E-pan, respectively. This means that total water consumptive use $\left(\mathrm{ET}_{\mathrm{a}}\right)$ was increased with increasing soil moisture regimes. Singh et al. (2007) observed higher soil moisture depletion at lower irrigation water: cumulative pan evaporation (IW/ $\mathrm{CPE}$ ) ratio. This was due to more water extraction by crop root from deeper layers under drier regime due to limited availability of moisture in the upper layers of the soil. The total water depletion from soil profile varied appreciably with soil moisture presented resulting from varying irrigation scheduling treatments (InmanBamber and Smith, 2005). Also the $\mathrm{ET}_{\mathrm{a}}$ values were increased as the level of potassium application increased at high soil moisture (1.2 CPE). While it showed an irregular trend at 0.8 and 1.0 CPE. This behav- 
ior might be due to that high soil moisture content support potassium absorption.

Irrigation efficiency (IE) decreased as the percentage of soil moisture depletion was increased (at $0.8 \mathrm{CPE}$ ). In general, IE ranged between 57.52 and $86.16 \%$ (Table 3). The obtained results revealed that regular irrigation with $1.2 \mathrm{CPE}$ at 75 $\mathrm{Kg} \mathrm{K} \mathrm{K}_{2} \mathrm{O} /$ fed achieved the highest value of irrigation efficiency $(86.16 \%)$ while the lowest value $(57.52 \%)$ was recorded at regular irrigation with $0.8 \mathrm{CPE}$ at $50 \mathrm{Kg} \mathrm{K}_{2} \mathrm{O} /$ fed.

Field water use efficiency (FWUE) defined as the weight of marketable crop production per the volume unit of applied irrigation water. Data in Table (3) showed that the irrigation manner and regimes were positively affected field water use efficiency. The average value of FWUE ranged between 2.09 and $5.44 \mathrm{Kg} / \mathrm{m}^{3}$. It is also, realized that increasing potassium levels increases the FWUE values. The highest FWUE value was attained in treatment of irrigated alternative furrow at 1.0 CPE with 75 $\mathrm{Kg} \mathrm{K}_{2} \mathrm{O} /$ fed. The lowest one was recorded in treatment of irrigated alternative furrow with $0.8 \mathrm{CPE}$ at $25 \mathrm{Kg}$ $\mathrm{K}_{2} \mathrm{O}$ / fed. The values of FWUE for sugar yield were $0.43,0.47$ and 0.51 $\mathrm{Kg}$ sugar/ $\mathrm{m}^{3}$ for $0.8,1.0$ and 1.2 $\mathrm{CPE}$, respectively.
Crop water use efficiency (CWUE) means the weight of marketable crop produced due to consumption of one $\mathrm{mm}$ water depth of soil moisture per feddan. In general, CWUE values were 5.38 and 5.91 $\mathrm{Kg} / \mathrm{m}^{3}$ for alternative and all furrow irrigation, respectively (Table 3 ). valus were $3.66,4.40$ and 3.23 at irrigation regime of $0.8,1.0$ and 1.2 $\mathrm{CPE}$, respectively. The data indicated that CWUE increased up to $1.0 \mathrm{CPE}$ and decreased thereafter to $1.2 \mathrm{CPE}$. This caused high CPE at the driest irrigation. This might be due to the plant crop extracted water from deeper layers even at lower moisture regimes. More water applied under 1.2 CPE did not give any advantage to the sugarcane crop. At this water regime, the crop tended to lodge and therefore registered lower yields. Excess irrigation also impedes aeration and hinders certain beneficial reactions within the plant and soil. Whereas water deficit promotes pith formation in cane resulting in reduced yield (Singh et al., 2007). The values of CWUE for sugar yield were 0.69, 0.74 and $0.77 \mathrm{Kg}$ sugar/ $\mathrm{m}^{3}$ for 0.8 , 1.0 and $1.2 \mathrm{CPE}$, respectively. It was observed that the best treatment was alternative irrigated furrow at 1.0 CPE when fertilized by $75 \mathrm{Kg} \mathrm{K}_{2} \mathrm{O}$ / fed since it realized the highest CWUE $\left(8.86 \mathrm{Kg}\right.$ cane $/ \mathrm{m}^{3}$ and $1.1 \mathrm{Kg}$ sugar $\left./ \mathrm{m}^{3}\right)$. 
Table (3): Irrigation water parameters and their efficiency for sugarcane crop as influenced by irrigation regime, manner and potassium fertilization.

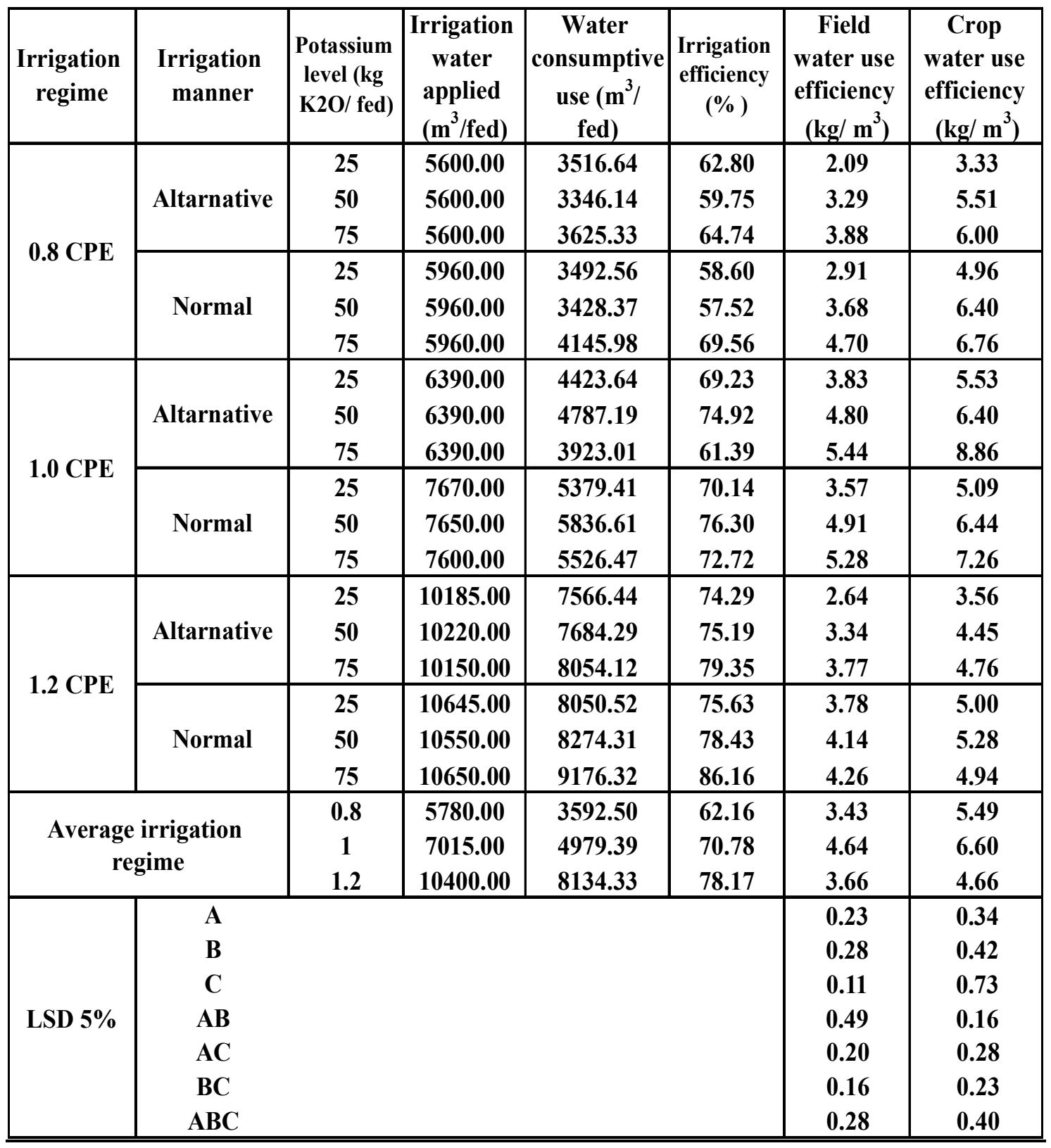

$\overline{C P E}=$ Cumulative pan evaporation $\quad \mathrm{A}=$ irri. regime

2- Sugarcane yield and quality

Sugarcane yield responses to irrigation water stress either by the irrigation way or intervals and potassium fertilization is shown in fig. (2). In general, data showed that sugarcane yield was increased by increasing both $\mathrm{CPE}$ and potassium fertilization levels. Sugarcane yield responded to irrigation intervals and hide the effect of irrigation way on sugarcane yield. The highest sugarcane yield (45.33 ton/ fed) was recorded in plots with all irrigated furrow at $1.2 \mathrm{CPE}$ when fertilized by 75 $\mathrm{Kg} \mathrm{K}_{2} \mathrm{O}$ / fed. The lowest one (11.72 ton/ fed) was recorded in plots with alternative irrigated furrow at 0.8 CPE when fertilized by $25 \mathrm{Kg} \mathrm{K}_{2} \mathrm{O} /$ fed. Wiedenfeld (2000) revealed that 
the effect of water stress appeared to be primarily related to the degree of stress relative to the evapotranspira- tion (ET) demand rather than the growth phase during which the stress occurred.

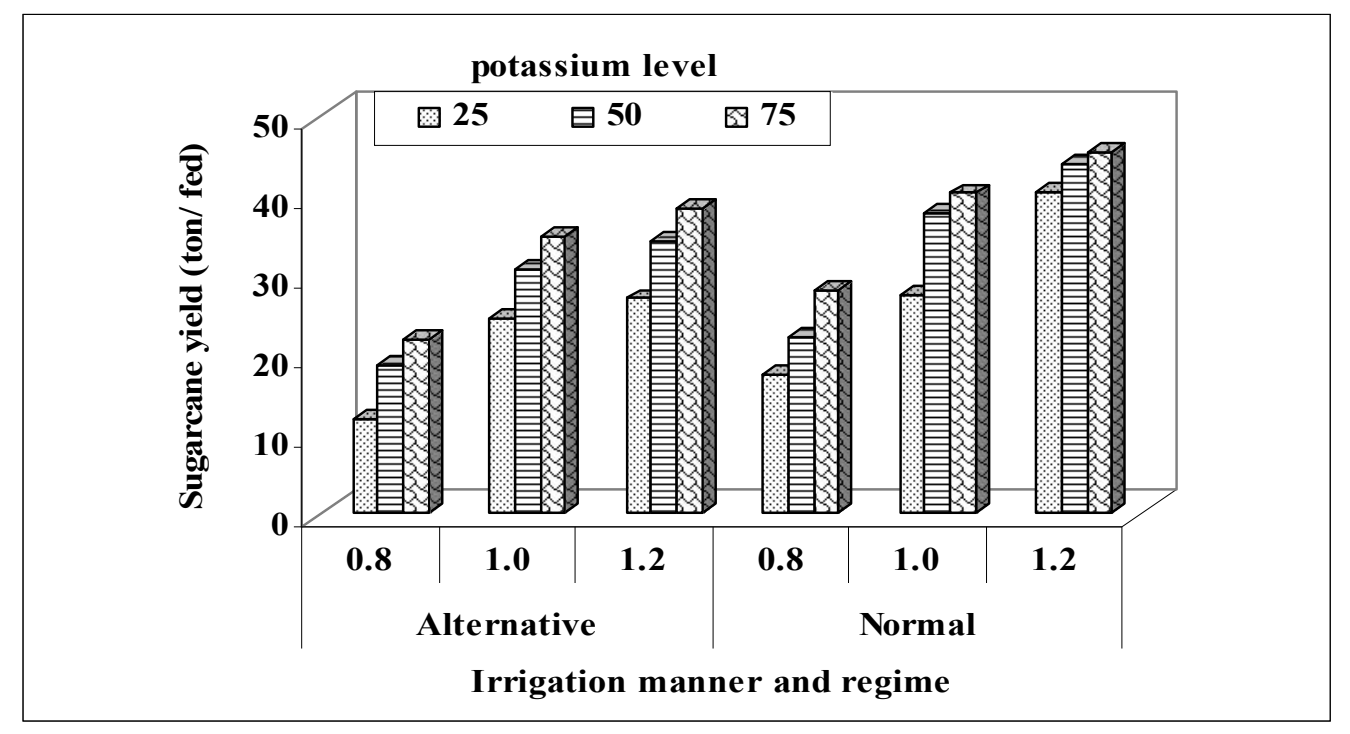

Fig. (2): Sugarcane yield in relation to irrigation way and regime at different levels of potassium fertilization.

In general, sugarcane stalk growth was positively responded to the irrigation scheduling treatments and $\mathrm{K}$ fertilization levels. Sugarcane stalk length was higher under all irrigated furrow treatments than those under alternative irrigated furrow (table 4). The stalk length was increased as both the CPE and $\mathrm{K}$ level was increased. Sugarcane stalk diameter showed a weak response to the irrigation scheduling or potassium treatments in the plant crop. Cane yield as well as juice purity and sugar concentration declined, resulting in decreased sugar yield as irrigation intervals was increased. Also, cane yield and its quality was increased by increasing potassium fertilization level (Table 4). The same trend was realized for brix $\%$. This result may be due to the increasing irrigation frequency, i.e., at the shortest intervals, which increased water content in stalks and hence decreased brix percentage. These finding coincided with those obtained by Wiedenfeld (2004) and Bekheet (2006).

\section{Conclusion:}

It might be concluded that sugarcane growth and yields responded primarily to the total amount of water applied. The irrigation levels prescribed by the scheduling methods were less than the amount necessary to obtain maximum yields. Sugarcane is very sensitive to available soil water contents, and that every effort should be made to maintain optimum moisture in the soil at all times during growth season. There is a need to better understand the consequences of variable timing and duration of water deficit during the first half of the growth period on sugarcane productivity, in terms of biological and commercial yield. 
Table (4): Sugarcane stalk properties, juice quality and sugar yield as affected by irrigation scheduling and potassium fertilization.

\begin{tabular}{|c|c|c|c|c|c|c|c|c|c|}
\hline \multicolumn{2}{|c|}{ irrigation } & \multirow{2}{*}{ K level } & \multicolumn{2}{|c|}{ stalk(cm) } & \multirow{2}{*}{$\begin{array}{c}\text { brix/ } \\
100 \mathrm{~cm} 3\end{array}$} & \multirow{2}{*}{$\begin{array}{c}\text { sugar/ } \\
\text { cm3 }\end{array}$} & \multirow{2}{*}{$\begin{array}{c}\text { purity } \\
\%\end{array}$} & \multirow{2}{*}{$\begin{array}{c}\text { sugar yield } \\
\text { (ton/fed) }\end{array}$} & \multirow{2}{*}{$\begin{array}{r}\text { cane yield } \\
\text { (ton/fed) }\end{array}$} \\
\hline stress & manner & & length & diameter & & & & & \\
\hline \multirow{8}{*}{ 0.8 CPE } & \multirow{3}{*}{ Alternative } & 25 & 158.70 & 2.70 & 23.39 & 19.88 & 85.01 & 1.45 & 11.72 \\
\hline & & 50 & 175.00 & 2.70 & 23.32 & 19.62 & 84.07 & 2.24 & 18.43 \\
\hline & & 75 & 207.70 & 2.90 & 23.41 & 20.12 & 85.95 & 2.74 & 21.75 \\
\hline & \multicolumn{2}{|c|}{ mean } & 180.47 & 2.77 & 23.37 & 19.87 & 85.01 & 2.14 & 17.30 \\
\hline & \multirow{3}{*}{ normal } & 25 & 193.70 & 2.80 & 23.94 & 20.98 & 87.62 & 2.29 & 17.33 \\
\hline & & 50 & 215.30 & 2.80 & 23.28 & 19.96 & 85.71 & 2.74 & 21.95 \\
\hline & & 75 & 203.70 & 2.90 & 23.72 & 20.22 & 85.23 & 3.53 & 28.02 \\
\hline & \multicolumn{2}{|c|}{ mean } & 204.23 & 2.83 & 23.65 & 20.39 & 86.19 & 2.85 & 22.43 \\
\hline \multicolumn{3}{|c|}{ mean } & 192.35 & 2.80 & 23.51 & 20.13 & 85.60 & 2.50 & 19.87 \\
\hline \multirow{8}{*}{ 1.0 CPE } & \multirow{3}{*}{ Alternative } & 25 & 167.00 & 2.80 & 24.26 & 21.13 & $8 \overline{87.07}$ & 3.25 & 24.47 \\
\hline & & 50 & 196.00 & 2.80 & 23.68 & 20.43 & 86.28 & 3.93 & 30.65 \\
\hline & & 75 & 220.00 & 2.90 & 23.30 & 19.87 & 85.27 & 4.30 & 34.74 \\
\hline & \multicolumn{2}{|c|}{ mean } & 194.33 & 2.83 & 23.75 & 20.48 & 86.21 & 3.83 & 29.95 \\
\hline & \multirow{3}{*}{ normal } & 25 & 204.70 & 2.80 & 23.37 & 20.04 & 85.76 & 3.43 & 27.40 \\
\hline & & 50 & 217.00 & 2.70 & 23.93 & 20.97 & 87.66 & 4.97 & 37.58 \\
\hline & & 75 & 227.00 & 2.70 & 23.83 & 20.92 & 87.71 & 5.30 & 40.14 \\
\hline & \multicolumn{2}{|c|}{ mean } & 216.23 & 2.73 & 23.71 & 20.64 & 87.04 & 4.57 & 35.04 \\
\hline \multicolumn{3}{|c|}{ mean } & 205.28 & 2.78 & 223.73 & 20.56 & 86.63 & 4.20 & 32.50 \\
\hline \multirow{8}{*}{ 1.2 CPE } & \multirow{3}{*}{ Alternative } & 25 & 2222.70 & 2.90 & 23.27 & 1919.67 & 84.49 & 3.29 & 26.91 \\
\hline & & 50 & 226.70 & 2.90 & 23.04 & 19.80 & 85.77 & 4.50 & 34.17 \\
\hline & & 75 & 216.70 & 2.90 & 24.14 & 21.25 & 88.07 & 5.14 & 38.31 \\
\hline & \multicolumn{2}{|c|}{ mean } & 222.03 & 2.90 & 23.48 & 20.24 & 86.11 & 4.31 & 33.13 \\
\hline & \multirow{3}{*}{ normal } & 25 & 230.70 & 2.80 & 24.27 & 21.38 & 92.33 & 5.87 & 40.22 \\
\hline & & 50 & 232.30 & 2.90 & 23.95 & 20.82 & 86.88 & 5.96 & 43.71 \\
\hline & & 75 & 243.70 & 3.00 & 23.43 & 20.31 & 86.68 & 5.79 & 45.33 \\
\hline & \multicolumn{2}{|c|}{ mean } & 235.57 & 2.90 & 23.88 & 20.84 & 88.63 & 5.87 & 43.09 \\
\hline \multicolumn{3}{|c|}{ mean } & 2228.80 & 2.90 & 23.68 & 20.54 & $\begin{array}{l}87.37 \\
\end{array}$ & $\begin{array}{c}.09 \\
\end{array}$ & 38.11 \\
\hline & $\mathbf{A}$ & & 2.93 & N.S. & N.S. & N.S. & N.S. & 0.42 & 1.68 \\
\hline & B & & 1.37 & N.S. & N.S. & N.S. & N.S. & 0.37 & 1.89 \\
\hline & C & & 1.72 & N.S. & N.S. & N.S. & N.S. & 0.22 & 0.96 \\
\hline LSD 5\% & $\overline{A B}$ & & 2.37 & N.S. & N.S. & N.S. & N.S. & N.S. & 3.28 \\
\hline & $\overline{\mathrm{AC}}$ & & 2.97 & N.S. & N.S. & N.S. & N.S. & N.S. & 1.66 \\
\hline & $\mathrm{BC}$ & & 2.43 & N.S. & N.S. & N.S. & N.S. & N.S. & N.S. \\
\hline & $\overline{\mathrm{AB}}$ & & 4.20 & N.S. & N.S. & N.S. & N.S. & 0.53 & 2.35 \\
\hline
\end{tabular}

References:

Ahmadi, S.H.; M.N. Andersen; F. Plauborg ; R.T.Poulsen; , C.R .Jensen; A.R. Sepaskhah and S. Hansen 2010. Effects of irrigation strategies and soils on field grown potatoes: yield and water productivity. Agricultural Water Management 97, 1923-1930.

Ashley, M.K.; M. Grant and A. Grabov 2006. Journal of Experimental Botany 57, 425-436.
Azevedo, P.V.; I.F. Sousa; B.B. Silva and V.P.R. Silva 2006. Wateruse efficiency of dwarf green coconut (Cocos nucifera L.) orchards in northeast Brazil. Agricultural Water Management 84, 259-264.

Bekheet, M.A. 2006. Effect of irrigation and potassium fertilization on yield and quality of two sugarcane varieties. Assiut J. Agric. Sci., 37(1): 1-19. 
Bierman, P.M. and C.J. Rosen 2005. Nutrient Cycling \& Maintaining Soil Fertility in Fruit and Vegetable Crop Systems. http:/www.extension.umn.edu/ distribution/ horticulture/m1193.html.

Cesnik, R.and J. Miocque 2004. Melhoramento da cana-de-açúcar. Embrapa Informação Tecnológica, Brasília, DF, Brazil

Chen, J.C.P. and C.C. Chou 1993. Cane sugar handbook: a manual for cane sugar manufacturers and their chemicals. 12th ed. John Wiley \& Sons, Inc., NY. Pp. 560.

FAO 2012. http://www.fao.org/nr /water/docs/Installation_of_ETo Calculator_V3.2.pdf

Freed, R. S. P.; S. P. Eisensmith; S. Goetez ; D. Recosky; V. W. Smail and P. Wolberg 1989. User,s Guide MSTAT-C Asoftwere program for the design management and analysis of agronomic research experiments. Michingan State University, U.S.A.

Gomez, K. A. and A. A. Gomez 1984. Statistical Procedures for Agricultural Research. A. Willey- Interscience Publication. New York 678 pp.

Inman-Bamber, N.G. and D.M. Smith. 2005. Water relations in sugarcane and response to water deficits. Field Crops Research $92: 185-202$.

Israelson, O.W. and V.E. Hansen 1962. Flow of water into and through soils. Irrigation principles and practices. 3rd Edition, John Wiley and Sons, Inc., New York, N. Y., U.S.A.

James, L. G. 1988. Principles of farm irrigation systems design.
Washington State University. $543 \mathrm{pp}$.

Klut, A.1986.Methods of soil analysis.part 1:physical and mineralogical methods ( $2^{\text {nd }}$ edition) Amirca Society of Agronomy Inc., Madison, Wisconsin, USA.

Lingle, S.E. ; R.P. Wiedenfeld and J.E. Irvine. 2000. Sugarcane response to saline irrigation water. J. Plant Nutrition, 23:469-486.

Medina, N.H.; M. L.T. Branco; M.A.G. Silveira and R.B.B.Santos 2013. Dynamic istribution of potassium in sugarcane Journal of Environmental Radioactivity 126:172-175.

Nilberto,H.M.; M.L.T. Branco; M.A.G. Silveira and R.B.B. Santos. 2013 Dynamic distribution of potassium in sugarcane. Journal of Environmental Radioactivity $126: 172-175$.

Page, A. L.; R.H. Miller and D.R. Keeney.1982. Methods of soil analysis. Part 2 : chemical and microbiological properties, $\left(2^{\text {nd }}\right.$ edition). Am-Soc. Of Agron.Inc. Soil Sci.Soc. of Am.,Madison, Wisconsin, USA.

Qureshi, S.A.; C.A. Madramootoo and G.T.Dodds .2002. Evaluation of irrigation schemes for sugarcane in Sindh, Pakistan, using SWAP93. Agricultural Water Management 54: 37-48.

Sander, J.Z. and W.G.M. Bastianssen 2004. Review of measured crop water productivity values for irrigated wheat, rice, cotton and maize. Agric. Water Manage. 69 (2), 115-133.

Sepaskhah, A.R. and S.N. Hosseini 2008. Effects of alternate furrow irrigation and nitrogen application rates on yield and waterand nitrogen-use efficiency of winter wheat (Triticum aesti- 
vum L.). Plant Production Science 11 (2): 250-259.

Shawky, M.E. 1967. Micro and macro pore-space distribution in profiles of typical Egyptian soils and factors affecting them. M.SC. Thesis, Fac. of Agric., Cairo Univ., A.R.E.

Silveira, M.A.G.; N.H. Medina ; R.H. Moreira ; V.A.P. Aguiar and B.S. Bellini 2009a. AIP Conference Proceedings 1265, $465 \mathrm{e} 466$.

Silveira, M.A.G.; R.H. Moreira ; A.L.C. de Paula and N.H. Medina 2009b. AIP Conference Proceedings 1139, 153.

Singels, A. 2007. A new approach to implementing computer-based decision support for sugarcane farmers and extension staff. The case of My Canesim.SugarCane Int.26:22-25.

Singh, P.N.; S.K. Shukla and V.K. Bhatnagar. 2007. Optimizing soil moisture regime to increase water use efficiency of sugarcane (Saccharum spp. Hybrid complex) in subtropical India. Agricultural WaterManagement $90: 95-100$.
Singh, R. K. and G. P. Singh 1998. Effect of sampling time on efficacy of selection for quality traits in sugarcane. Sugarcane, 3: 13-17.

UNSCEAR e United Nations Scientific Committee on the Effects of Atomic Radiation, 2000. Sources and Effects of Ionizing Radiation (United Nations, New York).

Velasco, H.; A.S. Cid; R.M. Anjos ; C. Zamboni ; M. Rozzotto ; D.L. Valladares and J.J. Ayub 2012. Journal of Environmental Radioactivity 104, 64e70.

Vites, F. G. 1965. Increasing water use efficiency by soil management. America Society Agronomy, Madison, Wisconsin, p. 259-274.

Wiedenfeld, B. 2004. Scheduling water application on drip irrigated sugarcane. Agricultural Water Management $64: 169-181$.

Wiedenfeld, R. P. 2000.Water stress during different sugarcane growth periods on yield and response to $\mathrm{N}$ fertilization. Agricultural Water Management 43: 173-182. 


\section{تأثثير الري التبادلي و التسميد البوتاسي على محصول قصب السكر}

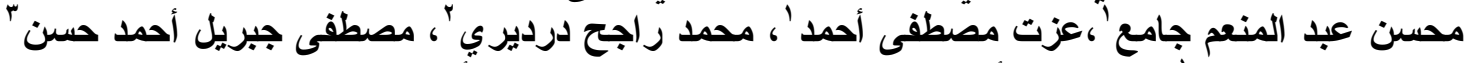

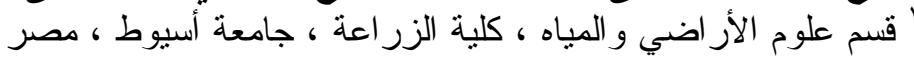

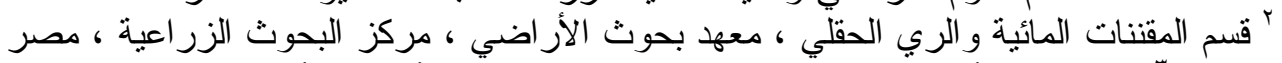

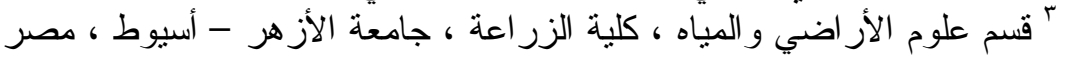

أجريت تجربة حقلية في المزرعة البحتية بمحطة البحوث الزر اعية بالمطاعنة - الأقــصر

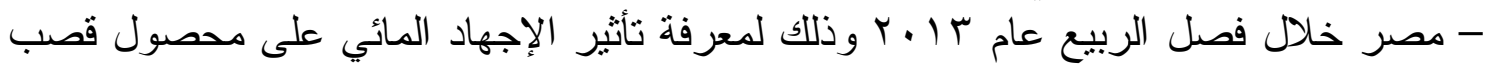

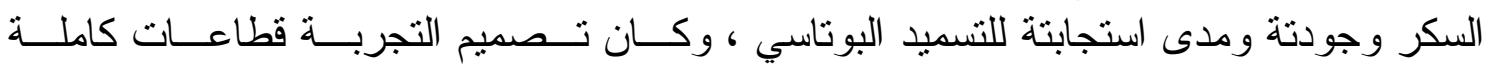

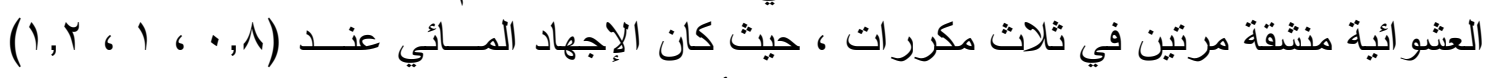

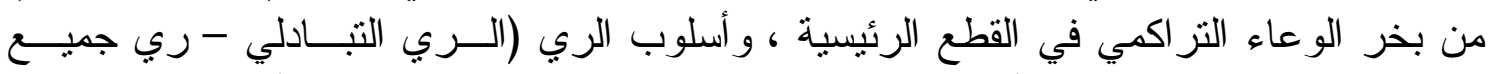

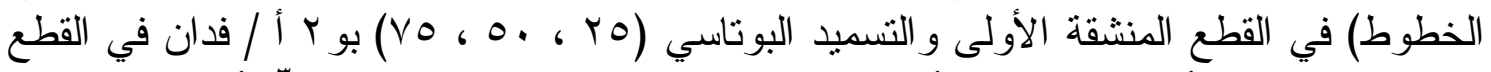

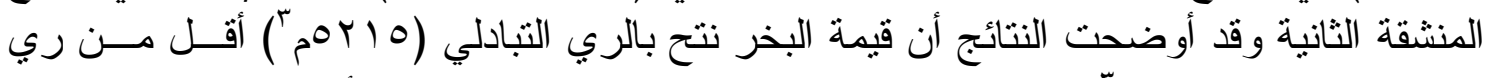

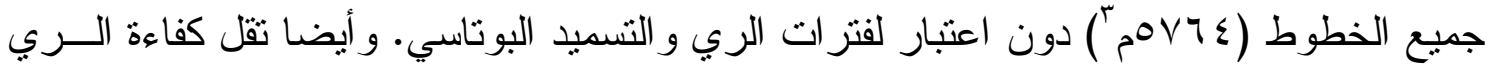

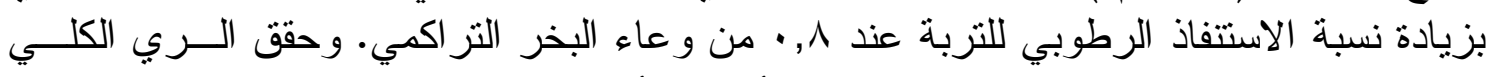

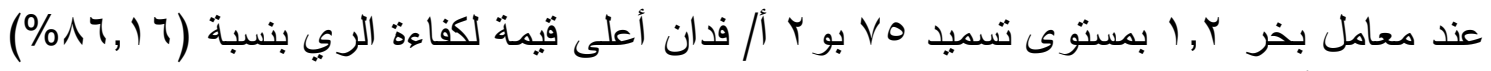

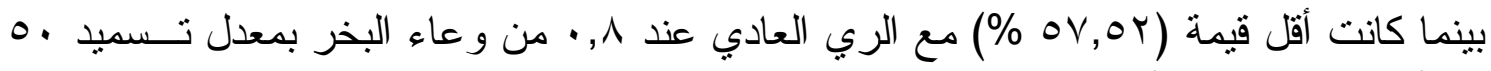

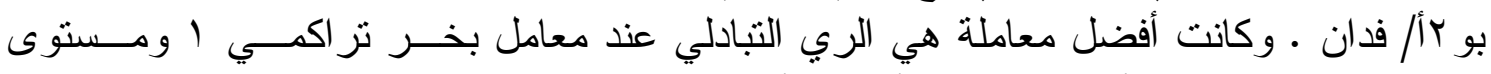

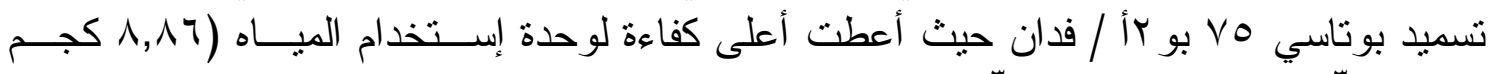

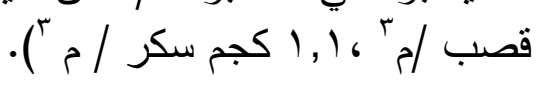

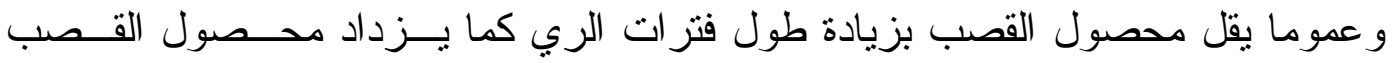

وتتحسن صفاته بزيادة مستوى التسميد البوتاسي. 